\title{
Self -image and selected clinical variables in the context of childhood abuse in subjects with alcohol dependence
}

\author{
Obraz siebie oraz wybrane zmienne kliniczne w kontekście przemocy doznawanej w dzieciństwie \\ u osób z zespołem uzależnienia od alkoholu
}

Aneta Gerhant ${ }^{1}$ ABCDEF https://orcid.org/0000-0002-4196-5437

Marcin Olajossy ${ }^{1}$ AD https://orcid.org/0000-0002-1001-3185

${ }^{1}$ II Department of Psychiatry and Psychiatric Rehabilitation, Medical University of Lublin, Poland

\begin{abstract}
Objective: The objective of the study was to determine the differences in selected clinical variables and self-image in people with alcohol dependence differing in severity of physical, emotional and sexual abuse experienced before age 18.

Method: The study included 90 people with alcohol dependence. The following research tools were used: Early Trauma Inventory (ETI), Adjective Check List (ACL), MAST, SAAD, and a questionnaire designed by the authors. In order to identify groups with varying indices of physical, emotional and sexual childhood abuse, a cluster analysis method was used. Results: Two groups of subjects with alcohol dependence were identified: Group 1 with high indices of physical, emotional and sexual childhood abuse and Group 2 with low indices. In terms of self-image the subjects in Group 1 compared to subjects in Group 2 were characterized by a lower self-esteem, self-acceptance, resistance to stress, less intense needs for achievement, endurance, order, nurturing others, interaction with opposite-sex partners, subordinations but more intense need for change. The age of alcohol use initiation and the onset of regular alcohol drinking was statistically significantly lower in Group 1. The severity of alcohol dependence was significantly lower in Group 2. The subjects in Group 1 significantly more frequently confirmed the history of a hereditary predisposition to alcohol dependence, suicidal ideation, suicide attempts and self-harm. Discussion: The obtained results closely correspond to the data available in the literature.

Conclusions: An assessment of exposure to various forms of childhood abuse appears to be an indispensable element of collecting medical history of people with alcohol dependence.
\end{abstract}

Keywords: alcohol dependence, alcohol use disorders, child abuse, self-image, suicide, self-mutilation.

\section{Streszczenie}

Cel: Celem badania było określenie różnic w zakresie wybranych zmiennych klinicznych oraz obrazu siebie u osób uzależnionych od alkoholu różniących się nasileniem przemocy fizycznej, emocjonalnej i seksualnej doświadczanej przed 18 rokiem życia.

Metoda: Badaniem objęto 90 osób uzależnionych od alkoholu leczonych w całodobowym oddziale odwykowym. Zastosowano następujące narzędzia badawcze: Kwestionariusz Wczesnej Traumy -EDI, Test Przymiotnikowy ACL, test MAST, SAAD, oraz kwestionariusz własnej konstrukcji. W celu wyodrębnienia grup różniących się wysokością nasileniem nadużyć fizycznych, emocjonalnych i seksualnych w dzieciństwie zastosowano metodą analizy skupień.

Wyniki: Wyodrębniono dwie grupy osób uzależnionych od alkoholu: Grupę 1 z wysokimi indeksami nadużyć fizycznych, emocjonalnych i seksualnych w dzieciństwie oraz Grupę 2 z niskimi indeksami. W zakresie obrazu siebie badani z Grupy 1 w porównaniu do badanych z Grupy 2 charakteryzowali się niższą samooceną, niższym poziomem samoakceptacji, mniejszą odpornością na stres, mniejszą potrzebą porządku, wytrwałości, osiągnięć, kontaktów heteroseksualnych, podporządkowania oraz większą potrzebą zmiany. Badani z większym nasileniem przemocy w dzieciństwie charakteryzowali się niższym wiekiem inicjacji alkoholowej i początku systematycznego picia alkoholu, większym nasileniem uzależnienia od alkoholu, częstszym występowaniem dziedzicznego obciążenia uzależnieniem od alkoholu, prób samobójczych, myśli samobójczych oraz samouszkodzeń w przeszłości.

Dyskusja: Otrzymane wyniki ściśle korespondują z danymi dostępnymi w literaturze.

Wnioski: Ocena narażenia na różne formy przemocy w dzieciństwie wydaje się być nieodzownym elementem zbierania wywiadu chorobowego od osób uzależnionych od alkoholu. 
Słowa kluczowe: uzależnienie od alkoholu, zaburzenia używania alkoholu, przemoc w dzieciństwie, obraz siebie, samobójstwo, samouszkodzenia.

\section{Introduction}

Child abuse is defined in the literature on the subject as non-random behaviors incompatible with existing standards and norms of interacting with a child that cause physical or mental developmental damage or pose a threat to its development. Child abuse can take the form of physical, emotional or sexual maltreatment and may involve neglect of its basic physical, emotional and existential needs. Physical abuse refers to any nonaccidental violent behaviors relating to the child's body, such as spanking, pulling, physical maltreatment with the use of sophisticated techniques and tools, or causing non-accidental physical injury to a child. Any behaviors of sexual nature towards children intended to sexually satisfy an adult are construed as sexual abuse. In contrast, emotional abuse is defined as deliberate destruction or a significant reduction of a child's proper development through behaviors such as: verbal abuse, threats, emotional rejection, excessive demands and disregard for developmental capabilities [1].

It is estimated that physical, emotional and sexual abuse in childhood is experienced by, respectively, $19 \%, 12 \%$ and $5 \%$ of the general population [2]. Much higher percentages are recorded in people with alcohol dependence syndrome. Physical abuse during childhood is experienced by from $31 \%$ to $36 \%$ of subjects with this diagnosis, emotional abuse by from $21 \%$ to $46 \%$, and sexual abuse by from $9.7 \%$ to $24 \%$ of subjects [3-5]. Each type of child abuse is associated with a significantly higher risk of alcohol dependence in adolescence and adulthood [6-8].

Self-image is an organized set of features which an individual has acquired on the basis of the past and current experiences considered as personal and selfspecific. It determines the durability and repeatability of behaviors and makes it possible to predict them in different situations. It is a relatively constant structure, however, as a result of observing and realizing a repeated dissonance between perceived experiences and selfperception, it may undergo a slow change. Such a change can also occur suddenly, for example due to sustained psychological trauma. Self-image is formed on the basis of self-observation, internalizing the opinions of other people and the processes of comparing oneself with others [9]. People addicted to alcohol have a negative selfimage and low self-esteem [10-15]. A negative self-image in people with alcohol dependence may be a determinant of their destructive style of behavior and a result of negative reactions of their immediate environment and society to the consequences of their actions and attitudes
[10]. The experience of abuse in childhood has a negative impact on self-image and self-esteem in adulthood [1618]. A mistreated child eventually begins to see itself through the eyes of the abuser and creates a negative representation of itself on the basis of negative feedback from the immediate environment. A negative self-image of victims of childhood abuse can also be conditioned by the processes of social comparison with their peers who come from functional families [18]. In a study by Cavaiola et al. [19] concerning adolescents addicted to psychoactive substances, lower self-esteem was common in the subjects who experienced sexual and physical abuse in childhood. Similar results were obtained by Moran and Eckenrode [20] in a study which involved a group of young women. However, in the literature on the subject there are no studies searching for the relationship between the level of exposure to different forms of childhood abuse and the self-image in adults with alcohol dependence syndrome.

\section{Objective of the study}

The objective of the study was to search for groups of people with alcohol dependence differing in severity of physical, emotional and sexual abuse experienced before the age of 18 and subsequently, to look for differences between the identified groups regarding the current selfimage and such clinical variables as the severity of alcohol dependence, the age of alcohol use initiation, the age of onset of regular drinking, the presence of a hereditary predisposition to alcohol dependence, the history of suicidal ideation and suicide attempts and self-harm, as well as experience with drugs.

\section{Material and methods}

The study group comprised 50 men and 40 women addicted to alcohol undergoing drug treatment in a closed ward. The average age of patients was 37.17. The diagnosis of alcohol dependence was based on the ICD-10 criteria and a psychiatric assessment. The conditions for inclusion in the study were an informed consent to participate therein and at least a two-week period of abstinence from alcohol. The study was approved by the Committee on Bioethics of the Medical University of Lublin (No. KE-0254/145/2011).

The following methods of measurement have been used in the study:

1. The Early Trauma Inventory (ETI) by Bremner as adapted in Polish by Śpila et al. [21,22] The ETI questionnaire is a tool to evaluate the exposure to traumatic events, including abuse, before the age of 18 . The inventory consists of four parts: I - general traumas, 
II - physical punishment, III - emotional abuse and IV sexual events. In this study only parts II, III and IV of the questionnaire have been used. In each of these parts the subject is questioned on exposure to particular types of traumas before the age of 18. If the answer is affirmative, the subject determines, in section $\mathrm{A}$, at which age the abuse occurred for the first time: the preschool period (up to the age of 5), the school period (6-12 years of age), puberty (13-18 years of age). In the subsequent stage, in section $B$, the frequency of these events is specified on a six-level scale, from the lowest frequency (once a month) to the highest (daily). In order to determine the severity of various forms of traumas, an index is determined, being the sum of points obtained in parts A and B for each item in individual parts of the questionnaire. In section $A$ the subject receives 18 points if he/she first experienced abuse at the preschool age, 12 points - if at the school-age and 6 points - if in adolescence. The score of section B is considered to be a number from 1 to 6 .

2. The Adjective Checklist by H.B. Gough and A.B. Heilbrun in an authorized translation by Z. Płużek. The ACL is a tool designed to describe the self-image in the dimensions of the real and the ideal. It consists of 300 adjectives arranged in 37 scales. The real self-image is formed when the subject is asked to select those adjectives that can best describe him/her. The ideal self-image is a collection of adjectives that the subject would like to attribute to herself/himself. Adjectives indicating the occurrence of a given characteristic are scored +1 , and those that deny it -1 . The rough score in the scale is the algebraic sum of diagnostic adjectives selected by the individual for a particular scale. The calculated results are based on standards developed for men and women and are given on a 100-degree scale ( $M=50, S D=10)$ [23].

3. The Michigan Alcoholism Screening Test (MAST) by Seltzer [24], as adapted into Polish by Falicki [25]. The MAST is a self-assessment questionnaire consisting of 24 questions to which the subject answers "yes" or "no" receiving 1, 2, 5 points or the multiple of 5 points for diagnostic answers. The final score is the sum of points obtained. The MAST is used for alcohol dependence screening. Alcohol dependence is supported by the score of 5 points or more. For people with alcohol dependence it can be used to assess the severity of alcohol-related problems [24].

4. The Short Form Alcohol Dependence Data Questionnaire (SADD) by Raistrick, as adapted into Polish by Ziółkowski. The SADD test consists of 15 statements concerning the incidence of alcohol dependence symptoms. The subject selects one of four possible responses: "never", "sometimes", "often" or "almost always", for which he/ she receives $0,1,2,3$ points, respectively. The final score is the sum of points obtained. Mild alcohol dependence is supported by the score of from 1 to 9 points, moderate dependence from 10 to 19 points while severe dependence from 20 to 45 points [26,27].

5. The survey designed by the authors aimed to determine such variables as the age of alcohol use initiation, the age of onset of regular drinking, the history of suicidal ideation, suicide attempts, self-harm and exposure to drugs.

The results were statistically analyzed using STATISTICA 10.0 PL. In order to identify groups of patients with differing physical, emotional and sexual abuse indices, a non-hierarchical cluster analysis was used. The goodness-of-fit of the variables between the groups identified with normal distribution was checked using the Kolmogorov-Smirnov test with the Lilliefors amendment and the Shapiro-Wilk test. As no normality of the distribution of qualitative variables was found, the results are presented as the median and compared using the Mann-Whitney U test.

\section{Results}

Out of the sample of 90 subjects 2 groups were selected, which were characterized by a distinctive pattern of results in terms of indices of physical, emotional and sexual abuse. The division into two groups is justified by statistical and factual arguments: the size of subgroups which enables their comparison with respect to the specified variables and the perceived psychological importance of identified types. Group 1 ( $\mathrm{n}=20$ ) was characterized by significantly higher indices of physical $(p$ $=0.001)$, emotional $(\mathrm{p}=0.004)$ and sexual abuse $(\mathrm{p}=001)$ before the age of 18 than Group 2 ( $n=70)$ (Tab.1).

The data in Table 2 indicate that people with higher indices of childhood abuse (Group 1) compared with

Table 1. Average indices of emotional (INE), sexual (INS) and physical abuse (INF) in separate groups of people with alcohol dependence syndrome

\begin{tabular}{|c|c|c|c|c|c|c|}
\hline & \multicolumn{2}{|c|}{$\begin{array}{c}\text { Group } 1 \\
n=20\end{array}$} & \multicolumn{2}{|c|}{$\underset{n=70}{\text { Group }} 2$} & \multirow{2}{*}{$t$} & \multirow{2}{*}{$p$} \\
\hline & $M$ & $d s$. & $M$ & $d s$. & & \\
\hline INE & 257.20 & 84.23 & 56.34 & 47.91 & 13.73 & 0.001 \\
\hline INS & 60.30 & 147.14 & 6.37 & 24.93 & 2.96 & 0.004 \\
\hline$I N F$ & 177.70 & 91.26 & 48.06 & 35.38 & 9.70 & 0.001 \\
\hline
\end{tabular}


Group 2 subjects achieved significantly better results in the scales of the ALC such as Unfav ( $p=0.033)$, Cha ( $p=$ $0.013)$, Ac $(p=0.046)$ and significantly lower scores in the following scales: Fav ( $p=0.003)$, Iss ( $p=0.006)$, MLS ( $p=$ $0.005)$ End $(p=0.001)$, Ord $(p=0.001)$. Nur $(p=0.020)$, $\operatorname{Def}(p=0.016), A(p=0.009), N p(p=0.001)$.
People with alcohol dependence who experienced more intense childhood abuse (Group 1) describe themselves using a significantly larger number of unfavorable adjectives and fewer favorable ones. This means that compared with subjects in Group 2, they have lower self-acceptance and self-esteem. Subjects in Group 1

Table 2. Scores obtained in the ACL by the subjects in groups 1 and 2

\begin{tabular}{|c|c|c|c|c|}
\hline \multirow{2}{*}{ ACL scales } & Group 1 & Group 2 & \multirow{2}{*}{$\mathrm{Z}$} & \multirow{2}{*}{$\mathrm{p}$} \\
\hline & Median & Median & & \\
\hline No-Ckd (number of adjectives checked) & 31.00 & 32.00 & -0.45 & ns \\
\hline Fav (number of favorable adjectives) & 33.00 & 40.00 & -2.96 & 0.003 \\
\hline Unfav (number of unfavorable adjectives) & 52.00 & 49.00 & 2.14 & 0.033 \\
\hline Com (communality) & 34.00 & 36.00 & -0.38 & ns \\
\hline Ach (need for achievement) & 38.00 & 44.50 & -2.23 & 0.026 \\
\hline Dom (need for dominance) & 47.00 & 45.00 & -0.44 & $n s$ \\
\hline End (need for endurance) & 39.00 & 47.00 & -3.42 & 0.001 \\
\hline Ord (need for order) & 39.00 & 48.50 & -3.82 & 0.001 \\
\hline Int (need for intraception) & 35.00 & 39.00 & -1.23 & $n s$ \\
\hline Nur (need to nurture others) & 41.00 & 46.50 & -2.32 & 0.020 \\
\hline Aff (need for affiliation) & 40.00 & 44.50 & -1.82 & $n s$ \\
\hline Het (need for interaction with opposite-sex partners) & 42.00 & 47.00 & -2.03 & 0.043 \\
\hline Exh (need to exhibit oneself) & 49.00 & 51.00 & -0.35 & $n s$ \\
\hline Aut (need for autonomy) & 50.00 & 49.00 & 1.30 & $n s$ \\
\hline Agg (need for aggression) & 58.00 & 51.50 & 1.67 & $n s$ \\
\hline Cha (need for change) & 49.00 & 45.00 & 2.48 & 0.013 \\
\hline Suc (need for support from others) & 50.00 & 56.00 & -0.76 & $n s$ \\
\hline Aba (need of self-abasement) & 49.00 & 55.00 & -0.38 & $n s$ \\
\hline Def (need to subordinate to others) & 45.00 & 51.50 & -2.42 & 0.016 \\
\hline Crs (readiness for counselling) & 49.00 & 46.00 & 0.98 & $n s$ \\
\hline S-Cn (self-control) & 44.00 & 48.00 & -1.56 & $n s$ \\
\hline S-Cfd (self-confidence) & 43.00 & 45.00 & -1.41 & $n s$ \\
\hline P-adj (Personal adjustment) & 42.00 & 42.00 & -0.43 & $n s$ \\
\hline Iss (The ideal self scale) & 39.00 & 47.00 & -2.73 & 0.006 \\
\hline Cps (Creative personality scale) & 47.00 & 46.50 & -0.11 & $n s$ \\
\hline Mls (Military leader scale) & 36.00 & 40.50 & -2.83 & 0.005 \\
\hline Mas (Masculinity scale) & 44.00 & 43.00 & -0.06 & $n s$ \\
\hline Fem (Femininity scale) & 42.00 & 42.00 & 0.32 & $n s$ \\
\hline $\mathrm{Cp}$ (Critical parent) & 53.00 & 48.00 & 1.12 & $n s$ \\
\hline$N p$ (Nurturing parent) & 39.00 & 48.00 & -3.58 & 0.001 \\
\hline A (Adult) & 35.00 & 42.00 & -2.62 & 0.009 \\
\hline Fc (Free child) & 51.00 & 49.00 & 0.62 & $n s$ \\
\hline Ac (Adapted child) & 60.00 & 55.00 & 1.99 & 0.046 \\
\hline
\end{tabular}


are significantly less satisfied with their current situation, which is why they seek new experiences and stimuli. The results obtained in terms of task needs show that they are less disciplined, conscientious, orderly and persistent in achieving their goals and fulfilling their responsibilities than subjects in Group 2. They also have significantly less motivation to succeed in life, they find it more difficult to accept prescribed rules and regulations. In terms of interpersonal relations, subjects in Group 1 are less nurturing, more suspicious of others, more likely to avoid close relationships and to become defensive. They have less of a need to establish relationships with the opposite sex and derive less satisfaction therefrom. Subjects with higher indices of childhood abuse are less resistant to stress and social pressures and more easily disorganized in such circumstances than the subjects with lower indices. Fearing a result of a direct confrontation with the threatening reality, they are more likely to escape into a world of dreams and fantasies. The severity of alcohol dependence assessed by the MAST $(p=0.001)$ and SAAD $(p=0.002)$ questionnaires was significantly higher in Group 1 than in Group 2 (Tab. 3).

Table 3. The severity of alcohol dependence in Groups 1 and 2

\begin{tabular}{|l|c|c|c|c|}
\hline & Group 1 & Group 2 & \multirow{2}{*}{$Z$} & $p$ \\
\cline { 2 - 3 } & Median & Median & & \\
\hline MAST & 47.00 & 32.00 & 3.79 & 0.001 \\
\hline SAAD & 27.00 & 20.00 & 3.10 & 0.002 \\
\hline
\end{tabular}

The subjects who experienced more intense abuse in childhood turned to alcohol at a younger age $(\mathrm{p}=0.001)$ and started to drink alcohol regularly at an earlier stage $(\mathrm{p}$ $=0.009$ ). The median age of alcohol use initiation and the onset of regular drinking in Group 1 were, respectively, 15 and 18.5 years of age, while in Group 2, 16 and 22 years of age (Tab. 4).

Table 4. The age of alcohol use initiation and the onset of regular alcohol use in groups 1 and 2

\begin{tabular}{|l|c|c|c|c|}
\hline & Group 1 & Group 2 & \multirow{2}{*}{$Z$} & $p$ \\
\cline { 2 - 3 } & Median & Median & & \\
\hline $\begin{array}{l}\text { Age of alcohol use } \\
\text { initiation }\end{array}$ & 15 & 16 & 3.79 & 0.001 \\
\hline $\begin{array}{l}\text { Age of onset of } \\
\text { regular alcohol use }\end{array}$ & 18.5 & 22 & 3.10 & 0.002 \\
\hline
\end{tabular}

Hereditary predispositions to alcohol dependence concerned a significantly larger number of subjects with more severe childhood abuse ( $p=0.05)$. This predisposition was found in 17 persons (85\%) in Group 1 and in 41 persons (58.57\%) in Group 2. Suicidal ideation, suicide attempts and self-harm in the past were confirmed by 14 (70\%), 9 (45\%), 14 (70\%) of the subjects in Group 1. These were statistically significantly higher percentages than in the group of subjects who suffered less severe physical, emotional and sexual abuse. Also exposure to drugs concerned a significantly larger number of subjects in Group 1 ( $\mathrm{n}=11,55 \%)$ as compared with Group 2 ( $\mathrm{n}=9$, 12.86\%) (p=0.0001) (Tab. 5).

Table 5. A comparison of the selected clinical variables in groups 1 and 2

\begin{tabular}{|l|c|c|c|c|}
\hline & Group 1 & Group 2 & Chi $^{2}$ & $p$ \\
\hline $\begin{array}{l}\text { hereditary } \\
\text { predisposition to } \\
\text { alcohol dependence }\end{array}$ & $\begin{array}{c}85 \% \\
(n=17)\end{array}$ & $\begin{array}{c}58.57 \% \\
(n=41)\end{array}$ & 3.65 & 0.05 \\
\hline suicidal ideation & $\begin{array}{c}70 \% \\
(n=14)\end{array}$ & $\begin{array}{c}24.29 \% \\
(n=17)\end{array}$ & 14.40 & 0.0001 \\
\hline suicide attempts & $\begin{array}{c}45 \% \\
(n=9)\end{array}$ & $\begin{array}{c}12.86 \% \\
(n=9)\end{array}$ & 10.04 & 0.001 \\
\hline self-mutilation & $\begin{array}{c}70 \% \\
(n=14)\end{array}$ & $\begin{array}{c}18.57 \% \\
(n=13)\end{array}$ & 19.59 & 0.0001 \\
\hline
\end{tabular}

\section{Discussion}

Various trends and psychological concepts try to explain the phenomenon of becoming addicted. In the cognitive-behavioral approach, dysfunctional behaviors and emotions of an alcohol addict can be tried to explain on the basis of learning theory, taking into account the moderating role of cognitive processes. Addiction would be the result of established maladaptive cognitive-behavioral patterns of the person, environment and relationship with alcohol [28]. Childhood abuse, especially suffered from the closest relatives, is one of the factors forming negative cognitive structures. In the model proposed by Finkelhor and Browne [29] the major traumatizing factors in the context of sexual abuse in a child include traumatic sexualization, betrayal, helplessness and stigmatization. Although in this constellation such factors exist only in the context of sexual trauma, they can also be identified in other forms of child abuse. These traumatic dynamics are the cause of low self-esteem, fear of rejection, a sense of lack of control over one's life, lack of trust in other people and difficulties in entering into close relationships. It appears that the results of our study correspond to the model referred to above. Greater intensification of abuse in childhood in the group of people with alcohol dependence was associated with lower self-esteem, a greater distrust of others, a greater tendency to avoid establishing closer relationships and a tendency to adopt a defensive stance. The subjects with higher indices of childhood abuse also had a significantly lesser need to establish heterosexual relationships and experienced them as less rewarding. This way of functioning in social relations may limit the network of social, particularly functional, support (AA groups), which seems to be one of the key factors to 
help achieve and maintain abstinence [30,31]. Rosen et al. [32] indicate that worse effects of therapy in people addicted to psychoactive substances who experienced physical and sexual abuse in childhood result from deeper deficits in terms of social support and a greater difficulty in establishing the principles of cooperation and a therapeutic alliance. Therapeutic work with this group of patients is also impeded by such aspects of their real self as greater impulsivity, a confrontational attitude, a tendency to oppose the rules and regulations and a lower level of perseverance, discipline and order in action. Difficulties in establishing interpersonal relationships, planning and pursuing objectives, a confrontational attitude and impulsivity are associated with a higher risk of discontinuing abstinence after completing treatment for addiction within a year of the observation period [33]. In our study, people with alcohol dependence, who experienced protracted childhood abuse, describe themselves as less resistant to stress and social pressures and they avoid a direct confrontation with the threatening reality. Chuang [34] indicates that the preference of evasive coping strategies in people addicted to alcohol involves more intense alcohol use, as well as reduces the chances of abstinence.

The age of alcohol use initiation and the age of onset of regular drinking in subjects with more severe physical, emotional and sexual childhood abuse was significantly lower than in Group 2. The results are consistent with the findings of other authors who report a lower age of alcohol use initiation in victims of childhood abuse [35-39]. For example, in a study by Roth et al. [39], the age of alcohol use initiation in people who were exposed to stress during childhood was that of 14 . On the other hand, Waldrop et al. [38] indicate that victims of childhood abuse turn to alcohol for the first time at least 2 years earlier, and those who drink alcohol in excess - about 7 years earlier than those without such traumatic experiences. In the study by Dube et al. [36], alcohol use initiation at an earlier age in people experiencing abuse in childhood concerned all birth cohorts after 1900. It seems, therefore, that this regularity does not depend on factors changing over the years, such as access to alcohol, advertising, anti-alcoholic actions and campaigns. Early use of alcohol may be due to a greater need for stimulation as well as an attempt to self-medicate for psychological effects of victimization, such as low self-esteem, depression and other negative affective states [40]. Rothman et al. [39] showed that stressful events in childhood are more strongly associated with drinking in order to cope with stress rather than drinking for pleasure or companionship, regardless of the model of drinking present in the parents and their views on the subject. People who had suffered more severe childhood abuse achieved significantly higher scores on the MAST and SADD scales. According to Aranowska et al. [41], scores obtained in the MAST positively correspond with the severity of the social consequences of alcohol dependence, and the score obtained in the SADD - with the severity of physical dependence symptoms. The results obtained correspond with the results of other authors $[35,42,43]$. Growing up in a family with alcoholrelated problems increases the likelihood of being exposed to different forms of childhood abuse [42,44]. This is confirmed by the results of our study in which people, who had experienced more intense abuse before the age of 18, significantly more frequently confirmed the presence of a hereditary predisposition to alcohol dependence syndrome. This type of traumatic experience is a risk factor for this disease, independent from genetic predispositions [7,44,45]. Alcohol dependence is a major risk factor for suicidal ideation and behavior. Kessler et al. [46] indicate that the risk of suicide attempts and suicidal ideation is, respectively, 4.6 and 6.5-fold higher in people with alcohol dependence compared with healthy subjects. Yet, the risk of suicide attempts with a fatal outcome in this group of patients is nearly 10 times higher than in the general population [47]. The results of available studies suggest that suicidal behavior is more common in people with alcohol dependence who were childhood victims of physical and sexual abuse [48,49]. Similar conclusions can be drawn based on the results of our study, as the history of suicidal ideation and attempts was confirmed by, respectively, $70 \%$ and $45 \%$ of respondents with higher indices of physical, emotional and sexual childhood abuse, while in the group with lower indices - only $24 \%$ and $13 \%$. Self-harm is an act involving intentional infliction of pain to one's body which is not intended to result in death. The purpose of self-harm may include: reducing the level of internal tension, coping with negative emotions, the conversion of mental suffering into physical pain, restoring a sense of control over the situation, stimulation or communicating suffering to the environment [50]. In the general population the prevalence of self-harm reaches $4 \%$. [51] Significantly higher rates are found in clinical populations. According to Evren et al. [52-54], this type of self-destructive behavior can occur in $26 \%$ to $29 \%$ of people addicted to alcohol and are associated with more frequent experiences of physical and sexual abuse in childhood, early onset of alcohol dependence and a higher risk of suicidal behaviors. In the group of people included in our study self-injury occurred in $30 \%$ of the respondents, however, it was significantly more often confirmed by individuals who reported a greater severity of physical, emotional and sexual abuse in childhood.

Our study has several limitations. Firstly, it is a crosssectional study and the exposure to childhood abuse was assessed retrospectively. Secondly, the group studied was 
relatively small and its selection was not random.

\section{Conclusions}

An indispensable element of collecting medical history from alcohol addicts seems to be the question of exposure to different forms of childhood abuse, as this type of experience can predict a more difficult cooperation in the therapeutic process due to the greater severity of dependence, a tendency to withdraw from relationships, difficulties in respecting the rules, a low level of endurance and the need of self-improvement. When working with such patients diagnostic vigilance is necessary in order to identify suicidal and self-destructive behaviors.

Except of areas typical of addiction psychotherapy, an important element of working with a patient with childhood trauma should be reworking this problem, especially in the context of maladaptive cognitive patterns.

Moreover, during therapeutic work with a child, adolescents experiencing violence or even adults burdened with such a history of childhood, it is worth considering an in-depth diagnosis of addiction to psychoactive substances and expanding it on addiction prevention.

\section{Wstęp}

Przemoc wobec dziecka definiowana jest w literaturze jako nieprzypadkowe zachowania niezgodne $\mathrm{z}$ istniejącymi standardami i normami postępowania z dzieckiem, które powodują fizyczne lub psychiczne szkody rozwojowe lub stanowią zagrożenie dla jego rozwoju. Przemoc wobec dziecka może przybierać formę przemocy fizycznej, emocjonalnej lub seksualnej, jak również wiązać się $\mathrm{z}$ zaniedbywaniem jego podstawowych potrzeb fizycznych, emocjonalnych i egzystencjalnych. Przemoc fizyczne dotyczy wszelkich nieprzypadkowych agresywnych zachowań odnoszących się do ciała dziecka takich jak: klapsy, szarpanie, fizyczne maltretowanie z użyciem wymyślnych technik i narzędzi, lub powodowanie nieprzypadkowych urazów fizycznych u dziecka. Wszelkie zachowania o charakterze seksualnym wobec dzieci, które mają na celu dostarczenie satysfakcji erotyczną dorosłemu uznaje się za przemoc seksualną. Natomiast przemoc emocjonalną definiuje się jako rozmyślne niszczenie lub znaczne obniżanie możliwości prawidłowego rozwoju dziecka przez zachowania takie jak: wyzwiska, groźby, emocjonalne odrzucenie, nadmierne wymagania i nie liczenie się z możliwościami rozwojowymi [1].

Szacuje się, że przemocy fizycznej, emocjonalnej i seksualnej w dzieciństwie doświadcza odpowiednio 19\%, 12\% oraz 5 \% populacji ogólnej [2]. Znacznie wyższe odsetki odnotowuje się u osób z zespołem uzależnienia od alkoholu. Nadużyć fizycznych w dzieciństwie doświadcza od $31 \%$ do $36 \%$ badanych $\mathrm{z}$ tym rozpoznaniem, emocjonalnych od $21 \%$ do $46 \%$, a seksualnych od $9,7 \%$ do $24 \%[3,4,5]$. Każdy rodzaj przemocy wobec dziecka wiąże się z istotnie większym ryzykiem uzależnienia od alkoholu w okresie adolescencji jak i po osiągnięciu dojrzałości [6,7,8].

Obraz siebie jest zorganizowanym zespołem cech, których jednostka nauczyła się na podstawie wcześniejszych i aktualnych doświadczeń uznawać za własne i specyficzne dla siebie. Warunkuje on trwałość i powtarzalność zachowań oraz pozwala je przewidzieć $\mathrm{w}$ różnych sytuacjach. Jest on strukturą względnie stałą, jednak na skutek dostrzegania i uświadamia sobie powtarzającego się dysonans pomiędzy percypowanymi doświadczeniami a sposobem widzenia siebie może ulegać powolnym zmianom. Taka zmiana może wystąpić również w sposób nagły, na przykład na skutek doznanego urazu psychicznego. Obraz siebie kształtuje się w oparciu o samoobserwację, internalizację opinii innych osób oraz procesy porównywania się z innymi [9]. Osoby uzależnione od alkoholu charakteryzują się negatywnym obrazem własnej osoby oraz niską samooceną $[10,11,12,13,14,15]$. Negatywny obraz siebie u osób uzależnionych od alkoholu może być determinantem ich destrukcyjnego stylu zachowania jak i skutkiem negatywnych reakcji najbliższego otoczenia i społeczeństwa na konsekwencje ich działań i prezentowanych postaw [10]. Doświadczenia przemocy w dzieciństwie wpływają negatywnie na obraz siebie oraz samoocenę $w$ dorosłym wieku $[16,17,18]$. Źle traktowane dziecko z czasem zaczyna postrzegać siebie oczami prześladowcy oraz kreuje negatywną reprezentację siebie w oparciu o negatywne informacje zwrotne na swój temat płynące z najbliższego otoczenia. Negatywny obraz siebie u ofiar nadużyć w dzieciństwie może być również warunkowany procesami społecznego porównywania się z rówieśnikami, którzy pochodzą z dobrze funkcjonujących rodzin [18]. W badaniu Cavaiola i wsp. [19] dotyczącym adolescentów uzależnionych od substancji psychoaktywnych, niższą samoocenę posiadali ci badani, którzy doświadczyli przemocy seksualnej i fizycznej w dzieciństwie. Podobne wyniki uzyskali Moran i Eckenrode [20] w badaniu, którym objęto grupę młodych kobiet. W literaturze tematu brakuje jednak badań, poszukujących zależności między stopniem narażenia na różne formy przemocy w dzieciństwie a obrazem siebie u dorosłych osób z zespołem uzależnienia od alkoholu.

\section{Cel badania}

Celem badania było poszukiwanie grup osób 
uzależnionych od alkoholu różniących się nasileniem przemocy fizycznej, emocjonalnej i seksualnej doznawanej przed 18 rokiem życia a następnie poszukiwanie różnić między wyodrębnionymi grupami w zakresie realnego obrazu sobie oraz takich zmiennych klinicznych jak nasilenie uzależnienia od alkoholu, wiek inicjacji alkoholowej, wiek początku systematycznego picia alkoholu, obecność dziedzicznego obciążenia uzależnieniem od alkoholu, występowanie myśli, prób samobójczych oraz samouszkodzeń w wywiadzie.

\section{Materiał i metody}

Grupę badaną stanowiło 50 mężczyzn i 40 kobiet uzależnionych od alkoholu biorących udział w terapii odwykowej w warunkach oddziału zamkniętego. Średnia wieku badanych wynosiła 37,17 lat. Rozpoznanie uzależnienia od alkoholu postawiono w oparciu o kryteria klasyfikacji ICD-10 i ocenę psychiatry. Warunkami włączenia do badania była świadoma zgoda na udział w badaniu oraz co najmniej dwutygodniowy okres abstynencji od alkoholu. Badanie uzyskało pozytywną opinię Komisji Bioetycznej Uniwersytetu Medycznego w Lublinie (nr.KE-0254/145/2011).

W badaniu zastosowano następujące narzędzia:

1. Inwentarza Wczesnej Traumy (ETI -Early Trauma Inventory) autorstwa Bremnera w polskiej adaptacji Śpili i wsp. [21,22] Kwestionariusz ETI jest narzędziem służącym do oceny ekspozycji na traumatyczne wydarzenia, w tym przemoc, przed 18 rokiem życia. Inwentarz składa się z czterech części: I-ogólne przeżycia stresowe, II-nadużycia fizyczne, III-nadużycia emocjonalne, IV-nadużycia seksualne. W niniejszej pracy posłużono się jedynie II, III oraz IV częścią kwestionariusza. W każdej z tych części badany pytany jest fakt narażenia na poszczególne typy przemocy przed 18 rokiem życia. W przypadku odpowiedzi twierdzącej badany w podpunkcie A określa w, którym przedziale wiekowym nadużycie miało miejsce po raz pierwszy: okres przedszkolny (do 5 r.ż), okres szkolny (612 lat), okres dojrzewania (13-18 lat). W kolejnym etapie, w podpunkcie B, określana jest częstość tych zdarzeń w sześciostopniowej skali, od najmniejszej częstości (1 raz w miesiącu) do największej (codziennie).W celu określenia nasilenia poszczególnych form przemocy wyznacza się indeks, który jest sumą iloczynów punktów uzyskanych w części A i B każdej pozycji w poszczególnych częściach kwestionariusza. W punkcie A badany otrzymuje 18 punktów jeżeli po raz pierwszy przemocy doświadczył się w wieku przedszkolnym, 12 punktów w wieku szkolnym a 6 punktów w wieku dojrzewania. Za wynik w podpunkcie B uznaje się cyfrę do 1 do 6 .

2. Test Przymiotnikowego ACL (Adjective Checklist) autorstwa H.B. Gougha i A.B.Heilbruna w autoryzowanym przekładzie Z. Płużek. Test Przymiotnikowy ACL jest narzędziem przeznaczonym do opisu obrazu siebie w wymiarach realnym i idealny. Składa się z 300 przymiotników uporządkowanych w 37 skale. Realny obraz siebie powstaje, gdy badany jest proszony o zaznaczenie tych przymiotników, które najtrafniej go opisują. Idealny obraz siebie jest zbiorem tych przymiotników, które badany chciałby sobie przypisać. Test jest prosty i zrozumiały dla większości badanych, a jego wypełnienie zajmuje przeciętnie 15-20 minut. Przymiotniki świadczące o występowaniu danej cechy punktowane są +1 , a te które jej zaprzeczają -1 . Wynik surowy w skali jest sumą algebraiczną wybranych przez badanego przymiotników diagnostycznych dla danej skali. Wyniki przeliczone powstają w oparciu o normy opracowane dla kobiet i mężczyzn i podane są w skali 100-stopniowej ( $M=50, S D=10)$ [23].

3. Michigan Alcoholism Sceening Test (MAST) autorstwa Selezera [24] w polskiej adaptacji Falickiego [25]. Test MAST jest kwestionariuszem samooceny składającym się z 24 pytań, na które badany udziela odpowiedzi „tak”, „nie”, otrzymując za odpowiedzi diagnostyczne 1,2,5 punktów lub wielokrotność 5 punktów. Wynik końcowy jest sumą uzyskanych punktów. Test MAST służy do przesiewowej diagnostyki uzależnienia od alkoholu. Za występowaniem uzależnienia od alkoholu przemawia wynik 5 punktów i więcej. U osób uzależnionych od alkoholu może być on wykorzystywany do oceny nasilenia problemów alkoholowych [24].

4. Short Form Alcohol Dependence Data Questinnaire (SADD) autorstwa Raistricka w polskiej adaptacji Ziółkowskiego. Test SADD składa się z 15 twierdzeń dotyczących częstości występowania objawów uzależnienia od alkoholu. Badany wybiera jedną z 4 możliwych odpowiedzi : „nigdy”, „czasami”, „często”, „prawie zawsze”, za które otrzymuje odpowiednio 0,1,2,3 punkty. Wynik końcowy jest sumą uzyskanych punktów. Za uzależnieniem od alkoholu o łagodnym nasileniu przemawia wynik od 1 do 9 punktów, umiarkowanym od 10 do 19 punktów i głębokim nasileniu od 20 do 45 punktów[26,27].

5. Ankieta własnej konstrukcji za pomocą, której określono takie zmienne jak wiek inicjacji alkoholowej, wiek początku systematycznego picia alkoholu, występowanie myśli, prób samobójczych, samouszkodzeń oraz kontakt z narkotykami w wywiadzie.

Uzyskane wyniki poddano analizie statystycznej z wykorzystaniem oprogramowania STATISTICA 10.0 PL. Celem wyodrębnienia grup pacjentów różniących się wysokością indeksów nadużycia fizycznego, emocjonalnego oraz seksualnego zastosowano niehierarchiczną analizę skupień. Zgodność rozkładu między zmiennych pomiędzy wyodrębnionymi grupami 
z rozkładem normalnym sprawdzono przy pomocy testów Kołmogorowa-Smirnowa z poprawką Lillieforsa oraz testu W Shapiro-Wilka. Ponieważ zmienne ilościowe nie miały rozkładu normalnego, wyniki przedstawiono $\mathrm{w}$ postaci mediany i porównano za pomocą testu U Manna Whithneya.

\section{Wyniki}

Z całej grupy 90 osób wyodrębniono 2 podgrupy odznaczające się charakterystycznym układem wyników w zakresie indeksów nadużycia fizycznego, emocjonalnego i seksualnego. Podział na dwie podgrupy uzasadniają argumenty statystyczne oraz merytoryczne: liczebność podgrup pozwalająca na porównywanie ich pod względem określonych zmiennych oraz wyraźne znaczenie psychologiczne ujawnionych typów. Grupa $1 \quad(n=20)$ charakteryzowała się istotnie statystycznie wyższymi indeksami nadużycia fizycznego $(p=0,001)$, emocjonalnego $(p=0,004)$ oraz seksualnego $(p=001)$ przed 18 rokiem życia niż Grupa 2 (n=70) (tab.1).

Tabela 1. Średnie indeksy nadużycia emocjonalnego (INE), seksualnego (INS) i fizycznego (INF) w wyodrębnionych grupach osób z zespołem uzależnienia od alkoholu

\begin{tabular}{|l|c|c|c|c|c|c|}
\hline & \multicolumn{2}{|c|}{$\begin{array}{c}\text { Grupa 1 } \\
n=20\end{array}$} & \multicolumn{2}{c|}{$\begin{array}{c}\text { Grupa 2 } \\
n=70\end{array}$} & \multirow{2}{*}{$p$} \\
\hline & $M$ & $d s$. & $M$ & $d s$. & 13,73 & 0,001 \\
\hline INE & 257,20 & 84,23 & 56,34 & 47,91 & 2,96 & 0,004 \\
\hline INS & 60,30 & 147,14 & 6,37 & 24,93 & 9,70 & 0,001 \\
\hline INF & 177,70 & 91,26 & 48,06 & 35,38 & \\
\hline
\end{tabular}

Dane zamieszczone w tabeli 2. informują, że osoby o $(p=0,033)$, Cha $(p=0,013)$, Ac $(p=0,046)$ oraz istotnie wyższych indeksach nadużycia w dzieciństwie (Grupa 1) niższe wyniki w skalach: Fav ( $p=0,003)$, Iss ( $p=0,006)$, Mls w porównaniu z badanymi z Grupy 2, uzyskały istotnie $(p=0,005)$, End $(p=0,001)$, Ord ( $p=0,001), N u r(p=0,020)$, wyższe wyniki w takich skalach testu ALC jak :Unfav Def (p=0,016), A ( p=0,009), Np (p=0,001) (tab.2)

Tabela 2. Wyniki uzyskane w teście ACL przez badanych z Grupy 1 i 2

\begin{tabular}{|c|c|c|c|c|}
\hline \multirow{2}{*}{ Skale ACL } & Grupa 1 & Grupa 2 & \multirow{2}{*}{$\mathrm{Z}$} & \multirow{2}{*}{$\mathrm{p}$} \\
\hline & Mediana & Mediana & & \\
\hline No-Ckd (ogólna liczba wybranych przymiotników) & 31,00 & 32,00 & $-0,45$ & ns \\
\hline Fav (liczba przymiotników pozytywnych) & 33,00 & 40,00 & $-2,96$ & 0,003 \\
\hline Unfav (liczba przymiotników negatywnych) & 52,00 & 49,00 & 2,14 & 0,033 \\
\hline Com (typowość) & 34,00 & 36,00 & $-0,38$ & ns \\
\hline Ach (potrzeba osiągnięć) & 38,00 & 44,50 & $-2,23$ & 0,026 \\
\hline Dom (potrzeba dominacji) & 47,00 & 45,00 & $-0,44$ & $n s$ \\
\hline End (potrzeba wytrwałości) & 39,00 & 47,00 & $-3,42$ & 0,001 \\
\hline Ord (potrzeba porzq̨dku) & 39,00 & 48,50 & $-3,82$ & 0,001 \\
\hline Int (potrzeba rozumienia siebie i innych) & 35,00 & 39,00 & $-1,23$ & $n s$ \\
\hline Nur (potrzeba opiekowania się innymi) & 41,00 & 46,50 & $-2,32$ & 0,020 \\
\hline Aff (potrzeba afiliacji) & 40,00 & 44,50 & $-1,82$ & $n s$ \\
\hline Het (potrzeba kontaktów heteroseksualnych) & 42,00 & 47,00 & $-2,03$ & 0,043 \\
\hline Exh (potrzeba ujawniania siebie) & 49,00 & 51,00 & $-0,35$ & $n s$ \\
\hline Aut (potrzeba autonomii) & 50,00 & 49,00 & 1,30 & $n s$ \\
\hline Agg (potrzeba agresji) & 58,00 & 51,50 & 1,67 & $n s$ \\
\hline Cha (potrzeba zmiany) & 49,00 & 45,00 & 2,48 & 0,013 \\
\hline Suc (potrzeba wsparcia) & 50,00 & 56,00 & $-0,76$ & $n s$ \\
\hline Aba (potrzeba poniżania siebie) & 49,00 & 55,00 & $-0,38$ & $n s$ \\
\hline
\end{tabular}




\begin{tabular}{|l|l|l|l|l|}
\hline Def (potrzeba podporzq̨dkowania się) & 45,00 & 51,50 & $-2,42$ & 0,016 \\
\hline Crs (skala gotowość na poradnictwo) & 49,00 & 46,00 & 0,98 & $n s$ \\
\hline S-Cn (skala samokontroli) & 44,00 & 48,00 & $-1,56$ & $n s$ \\
\hline S-Cfd (skala zaufania do siebie) & 43,00 & 45,00 & $-1,41$ & $n s$ \\
\hline P-adj (skala przystosowania osobistego) & 42,00 & 42,00 & $-0,43$ & $n s$ \\
\hline Iss (skala idealnego obrazu siebie) & 39,00 & 47,00 & $-2,73$ & 0,006 \\
\hline Cps (skala osobowości twórczej) & 47,00 & 46,50 & $-0,11$ & $n s$ \\
\hline Mls (skala zdolności przywódczych) & 36,00 & 40,50 & $-2,83$ & 0,005 \\
\hline Mas (skala męskości) & 44,00 & 43,00 & $-0,06$ & $n s$ \\
\hline Fem (skala kobiecości) & 42,00 & 42,00 & 0,32 & $n s$ \\
\hline Cp (skala rodzica krytycznego) & 53,00 & 48,00 & 1,12 & $n s$ \\
\hline Np (skala rodzica opiekuńczego) & 39,00 & 48,00 & $-3,58$ & 0,001 \\
\hline A (skala dorosłego) & 35,00 & 42,00 & $-2,62$ & 0,009 \\
\hline Fc (skala dziecka wolnego) & 51,00 & 49,00 & 0,62 & $n s$ \\
\hline Ac (skala dziecka przystosowanego) & 60,00 & 55,00 & 1,99 & 0,046 \\
\hline
\end{tabular}

Osoby uzależnione od alkoholu, które doświadczyły intensywniejszej przemocy w dzieciństwie (Grupa1) opisują siebie używając istotnie większej ilość przymiotników negatywnych a mniejszej pozytywnych. Oznacza to, że w porównaniu do badanych z Grupy 2 w mniejszym stopniu akceptują siebie oraz mają niższe poczucie wartości. Badani w Grupy 1 są istotnie mniej zadowoleni ze swojej aktualnej sytuacji przez co przeszukują nowych doświadczeń i bodźców. Wyniki uzyskane w zakresie potrzeb zadaniowych informują, że są oni mniej zdyscyplinowani, obowiązkowi, uporządkowani i wytrwali w realizacji celów i wypełnianiu obowiązków niż badani z Grupy 2. Posiadają również istotnie mniejszą motywację do osiągania sukcesów w życiu, trudniej im zaakceptować narzucone z zewnątrz reguły i zasady. W zakresie relacji interpersonalnych badani z grupy 1 są mniej opiekuńczy, bardziej podejrzliwi w stosunku do innych osób, częściej unikają bliskich relacji oraz przyjmują w nich postawę obronną. Mają mniejszą potrzebę nawiązywania relacji $\mathrm{z}$ płcią przeciwną oraz czerpią z nich mniej satysfakcji. Osoby z wyższymi indeksami nadużycia w dzieciństwie są mniej odporne na stres i presję społeczną i łatwiej ulegają dezorganizacji w takiej sytuacji niż badani $\mathrm{z}$ niższymi indeksami. Obawiając się wyniku bezpośredniej konfrontacji z zagrażającą rzeczywistością, częściej uciekają w świat marzeń i fantazji.

Nasileniem uzależnienia od alkoholu oceniane za pomocą kwestionariuszy MAST $(\mathrm{p}=0,001)$ i SAAD ( $p=0,002)$ było istotnie większe w Grupie 1 niż 2 (tab.3).

Tabela 3. Nasilenie uzależnienia od alkoholu w Grupie 1 i 2
\begin{tabular}{|l|c|c|c|c|}
\hline & Grupa 1 & Grupa 2 & \multirow{2}{*}{$Z$} & $p$ \\
\cline { 2 - 5 } & Mediana & Mediana & & \\
\hline MAST & 47,00 & 32,00 & 3,79 & 0,001 \\
\hline SAAD & 27,00 & 20,00 & 3,10 & 0,002 \\
\hline
\end{tabular}

Mediany wieku inicjacji alkoholowej oraz początku systematycznego picia alkoholu w grupie 1 wynosiły odpowiednio 15 i 18,5 lat, natomiast w grupie 216 i 22 lata (tab.4).

Tabela 4. Wiek inicjacji alkoholowej i początku systematycznego używania alkoholu w Grupie 1 i 2

\begin{tabular}{|l|c|c|c|c|}
\hline & Grupa 1 & Grupa 2 & \multirow{2}{*}{$Z$} & $p$ \\
\cline { 2 - 4 } & Mediana & Mediana & & \\
\hline $\begin{array}{l}\text { Wiek inicjacji } \\
\text { alkoholowej }\end{array}$ & 15 & 16 & 3,79 & 0,001 \\
\hline $\begin{array}{l}\text { Wiek } \\
\text { zapoczatkowania } \\
\text { systematycznego } \\
\text { picia alkoholu }\end{array}$ & 18,5 & 22 & 3,10 & 0,002 \\
\hline
\end{tabular}

Dziedzicznie obciążenie uzależnieniem od alkoholu dotyczyło istotnie większej ilości badanych z większym nasileniem przemocy w dzieciństwie $(\mathrm{p}=0,05)$. Odciążenie to stwierdzono u 17 osób (85\%) z grupy oraz u 41 osób $(58,57 \%)$ z grupy 2 . Występowanie myśli samobójczych, prób samobójczych oraz samouszkodzeń w przeszłości potwierdzało odpowiednio 14 (70\%), 9 (45\%), 14 (70\%) respondentów z grupy 1 . Były to istotnie statystycznie wyższe odsetki niż $\mathrm{w}$ grupie $\mathrm{z}$ mniejszym nasileniem 
przemocy fizycznej, emocjonalnej i seksualnej. Również kontakt z narkotykami dotyczył większej istotnie większej liczby badanych z grupy 1 (n=11, 55\%) w porównaniu z grupą 2 ( $n=9,12,86 \%)(p=0,0001)$ (tab.5).

Tabela 5. Porównanie wybranych zmiennych klinicznych w Grupie 1 i 2

\begin{tabular}{|l|c|c|c|c|}
\hline & Grupa 1 & Grupa 2 & Chi $^{2}$ & $p$ \\
\hline $\begin{array}{l}\text { dziedziczne } \\
\text { obciażenie } \\
\text { uzależnieniem od } \\
\text { alkoholu }\end{array}$ & $\begin{array}{c}85 \% \\
(n=17)\end{array}$ & $\begin{array}{c}58,57 \% \\
(n=41)\end{array}$ & 3,65 & 0,05 \\
\hline myśli samobójcze & $\begin{array}{c}70 \% \\
(n=14)\end{array}$ & $\begin{array}{c}24,29 \% \\
(n=17)\end{array}$ & 14,40 & 0,0001 \\
\hline próby samobójcze & $\begin{array}{c}45 \% \\
(n=9)\end{array}$ & $\begin{array}{c}12,86 \% \\
(n=9)\end{array}$ & 10,04 & 0,001 \\
\hline samouszkodzenia & $\begin{array}{c}70 \% \\
(n=14)\end{array}$ & $\begin{array}{c}18,57 \% \\
(n=13)\end{array}$ & 19,59 & 0,0001 \\
\hline
\end{tabular}

\section{Dyskusja}

Różne nurty i koncepcje psychologiczne próbują wytłumaczyć zjawisko uzależniania się. W ujęciu poznawczo-behawioralnym dysfunkcjonalne zachowania i emocje osoby uzależnionej od alkoholu można więc spróbować wyjaśnić na podstawie teorii uczenia się $\mathrm{z}$ uwzględnieniem moderującej roli procesów poznawczych. Uzależnienie byłoby skutkiem utrwalonych dezadaptacyjnych schematów poznawczobehawioralnych dotyczących osoby, otoczenia i relacji z alkoholem. [28]. Jednym z czynników kształtującym negatywne struktury poznawcze jest doświadczenie przemocy w dzieciństwie, szczególnie ze strony osób najbliższych. W modelu zaproponowanym przez Finkelhor i Browne [29] głównymi czynnikami traumatyzującymi w kontekście przemocy seksualnej u dziecka są traumatyczna seksualizacja, poczucie zdrady, poczucie bezsilności oraz stygmatyzacja. Chociaż w takiej konstelacji czynniki te występują jedynie w kontekście traumy seksualnej, to można je zidentyfikować również w innych formach przemocy wobec dziecka. Powyższe dynamiki traumatyczne są przyczyną niskiego poczucia wartości, obawy przed odrzuceniem, poczucia braku kontroli nad życiem, braku zaufania do innych osób i trudności wchodzenia $\mathrm{w}$ bliskie relacje. Wydaje się, że wyniki naszego badania korespondują z powyższym modelem. Większe nasilenie przemocy $\mathrm{w}$ dzieciństwie w badanej grupie osób uzależnionych od alkoholu wiązało się niższą samooceną, większą nieufnością w stosunku do innych, większą skłonnością do unikania nawiązywania bliższych relacji oraz tendencją do przyjmowania w nich postawy obronnej .Badani w wyższymi indeksami nadużyć w dzieciństwie miały ponadto istotnie mniejszą potrzebę nawiązywania relacji heteroseksualnych i odczuwały je jako mniej satysfakcjonujące. Taki sposób funkcjonowania w relacjach społecznych może ograniczać sieć wsparcie społecznego, szczególnie funkcjonalnego (grupy AA), które wydaje się z być jednym z kluczowych czynników ułatwiających uzyskanie i utrzymywanie abstynencji [30,31]. Rosen i wsp. [32] informują, że gorsze efekty terapii u osób uzależnionych od substancji psychoaktywnych, które doświadczyły nadużyć fizycznych i seksualnych w dzieciństwie są wynikiem głębszych deficytów w zakresie wsparcia społecznego oraz większych trudności dotyczących ustanowienia zasad współpracy i przymierza terapeutycznego. Praca terapeutyczna z tą grupą pacjentów utrudniają również takie aspekty ich ja realnego jak większą impulsywność, konfliktowość, skłonność do przeciwstawianie się zasadom i regułom oraz niższy poziom wytrwałości, zdyscyplinowania i uporządkowania w działaniu. Trudności w nawiązywaniu kontaktów interpersonalnych, planowaniu i realizowaniu celów, konfliktowość oraz impulsywność wiążą się z większym ryzykiem przerwania abstynencji po ukończeniu terapii odwykowej w rocznym okresie obserwacji [33]. W naszym badaniu osoby uzależnione od alkoholu, które doświadczyły intensywniejszej przemocy w dzieciństwie opisywały siebie jako mniej odporne na stres i presję społeczną oraz unikające bezpośredniej konfrontacji z zagrażającą rzeczywistością. Chuang [34] informuje, że u osób uzależnionych od alkoholu preferowanie unikowych strategii radzenia sobie ze stresem wiąże się intensywniejszym używaniem alkoholu jak również zmniejsza szanse na uzyskanie abstynencji.

Wiek inicjacji alkoholowej oraz wiek zapoczątkowania systematycznego picia alkoholu $\mathrm{u}$ badanych z większym nasileniem przemocy fizycznej, emocjonalnej i seksualnej w dzieciństwie był istotnie niższy niż w grupie 2. Otrzymane wyniki są spójne z doniesieniami innych autorów, którzy informują o niższym wieku inicjacji alkoholowej u ofiar przemocy w dzieciństwie [35,36,37,38,39]. Na przykład badaniu Rotham i wsp. [39] wiek inicjacji alkoholowej u osób, które narażone były na narażony na stres w dzieciństwie wynosił 14 lat. Natomiast Waldrop i wsp [38] informują, że ofiary przemocy w dzieciństwie sięgają po alkohol po raz pierwszy o co najmniej 2 lata wcześniej, a te które piją alkohol w sposób intensywny o około 7 lat wcześniej niż osoby bez tego typu traumatycznych doświadczeń. W badaniu Dube i wsp. [36] wcześniejszy wiek inicjacji alkoholowej u osób doświadczających nadużyć w dzieciństwie dotyczył wszystkich kohorturodzeniowych po 1900 roku. Wydaje się więc, że prawidłowość ta nie zależy od czynników zmieniających się na przestrzeni lat takich jak dostęp do alkoholu, reklama, akcje i kampanie przeciwalkoholowe. Wcześniejsze sięganie po alkohol może wynikać z większego zapotrzebowania 
na stymulację jak również stanowić próbę samoleczenia psychologicznych skutków wiktymizacji takich jak niska samoocena, depresja i inne negatywne stany afektywne [40]. Rothman i wsp. [39] udowodnili, że stresujące wydarzenia w dzieciństwie silniej wiążą się z piciem alkoholu w celu radzenia sobie ze stresem niż z piciem dla przyjemności lub towarzystwa, niezależnie od modelu picia alkoholu obecnego u rodziców oraz ich poglądów na ten temat. Osoby z większym nasileniem przemocy w dzieciństwie osiągały istotnie wyższą punktację w skali MAST i SADD. Według Aranowskiej i wsp. [41] punktacja uzyskiwana $\mathrm{w}$ kwestionariuszu MAST koresponduje dodatnio $\mathrm{z}$ nasileniem społecznych konsekwencji uzależnienia od alkoholu, natomiast punktacja uzyskiwana $\mathrm{w}$ teście SADD $\mathrm{z}$ nasileniem fizycznych objawów uzależnienia. Otrzymane wyniki korespondują z wynikami badań innych autorów $[35,42,43]$. Dorastanie $\mathrm{w}$ rodzinie $\mathrm{z}$ problemem alkoholowym zwiększa prawdopodobieństwo narażania na różne formy przemocy w dzieciństwie $[42,44]$. Potwierdzają to wyniki naszego badania, w którym osoby, które doświadczały bardziej intensywnej przemocy w przed ukończeniem 18 roku życia istotnie częściej potwierdzały występowanie rodzinne obciążenie zespołem uzależniania od alkoholu. Tego typu traumatyczne doświadczenia są niezależnym od obciążenia genetycznego czynnikiem ryzyka tej choroby $[7,44,45]$. Uzależnienie od alkoholu jest ważnym czynnikiem ryzyka myśli i zachowań samobójczych. Kessler i wsp. [46] informują, że ryzyko prób i myśli samobójczych jest odpowiednio o 4,6 i 6,5-krotnie wyższe u osób uzależnionych od alkoholu w porównaniu ze zdrowymi. Natomiast ryzyko prób samobójczych ze skutkiem śmiertelnym $w$ tej grupie chorych jest niemal 10 razy większe niż w populacji ogólnej [47]. Wyniki dostępnych badań pozwalają przy puszczać, że zachowania samobójcze występują częściej u osób uzależnionych od alkoholu, które były w dzieciństwie ofiarami przemocy fizycznej i seksualnej $[48,49]$. Podobne wnioski można wysnuć na podstawie wyników naszego badania ponieważ myśli i próby samobójcze $\mathrm{w}$ wywiadzie potwierdziło odpowiednio 70\% i 45\% badanych z większymi indeksami nadużyć fizycznych, emocjonalnych i seksualnych w dzieciństwie, podczas gdy $\mathrm{w}$ grupie $\mathrm{z}$ niższymi indeksami jedynie $24 \%$ i $13 \%$. Samouszkodzenie to akt polegający na intencjonalnym zadawaniu swojemu ciału bólu, którego celem nie jest doprowadzenie do śmierci. Motywami dokonywania samouszkodzeń mogą być: obniżenie poziomu wewnętrznego napięcia, radzenie sobie $\mathrm{z}$ negatywnymi emocjami, zamiana cierpienia psychicznego na ból fizyczny, przywracanie poczucia kontroli nad sytuacją, stymulacja, komunikowane otoczeniu swojego cierpienia [50]. W populacji ogólnej rozpowszechnienie samouszkodzeń sięga 4\% [51].
Znacznie wyższe odsetki stwierdza się w populacjach klinicznych. Według Evren i wsp. [52-54] tego typu autodestrukcyjne zachowania mogą występować u $26 \%$ do $29 \%$ osób uzależnionych od alkoholu i wiążą się z częstszymi doświadczeniami nadużyć fizycznych i seksualnych w dzieciństwie, wcześniejszym początkiem uzależnienia od alkoholu oraz większym ryzykiem zachowań samobójczych. W grupie osób objętej naszym badaniem samouszkodzenia występowały u $30 \%$ respondentów, jednak istotnie częściej potwierdzały je osoby, które relacjonowały większe nasilenie przemocy fizycznej, emocjonalnej i seksualnej w dzieciństwie.

Nasze badanie posiada kilka ograniczeń. Po pierwsze jest to badanie przekrojowe a ocena narażenia na przemoc w dzieciństwie oceniana była retrospektywne. Po drugie grupa objęta badaniem była relatywnie mała a jej dobór nie był losowy.

\section{Wnioski}

Nieodzownym elementem zbierania wywiadu chorobowego od osób uzależnionych od alkoholu wydaje się być pytanie o narażenie na różne formy przemocy w dzieciństwie. Tego typu traumatyczne doświadczenia mogą prognozować trudniejszą współpracę w procesie terapeutycznym $\mathrm{z}$ uwagi na większe nasilenie uzależnienia, skłonność do wycofywania się z relacji, trudności w respektowaniu zasad, niski poziom wytrwałości i potrzeby samodoskonalenia się. W pracy z tego typu pacjentami należy zachować czujność diagnostyczną ukierunkowaną na skłonności do zachowań samobójczych.

Poza typowymi dla psychoterapii uzależnień tematami, ważnym elementem pracy $\mathrm{z}$ pacjentem obarczonym traumą dziecięcą, powinno być przepracowanie tego problemu szczególnie w kontekście dezadaptacyjnych schematów poznawczych.

Ponadto w pracy terapeutycznej z dzieckiem, młodzieżą doświadczającą przemocy lub nawet dorosłym obarczonym taką historią dzieciństwa, warto brać pod uwagę wnikliwą diagnozę $\mathrm{w}$ kierunku uzależnienia od substancji psychoaktywnych oraz poszerzać ją o profilaktykę uzależnień.

\section{Conflict of interest}

The authors have declared no conflict of interest.

\section{References}

1. Jarosz E. Dom, który krzywdzi. Katowice; „Śląsk” Wydawnictwo Naukowe :2001.

2. Scher CD, Forde DR, Mc Quaid JR, Stein MB. Prevalence and demographic correlates of childhood maltreatment in an adult community sample. Child Abuse Negl.2004; 28(2):167-80.

3. Bernstein DP, Stein JA, Handelsman L. Predicting personality pathology among adult patients with substance use 
disorders: Effects of childhood maltreatment. Addict Behav. 1998;23(6):855-68.

4. Huang MC, Schwandt ML, Ramchandani VA, George DT, Heilig M. Impact of multiple types of childhood trauma exposure on risk of psychiatric comorbidity among alcoholic inpatients. Alcohol Clin Exp Res. 2012; 36(6):1099-107.

5. Potthast N, Neuner F, Catani C. The contribution of emotional maltreatment to alcohol dependence in a treatment-seeking sample. Addict Behav. 2014; 39(5): 949-58.

6. Anda RF, Felitti VJ, Bremner JD, Walker JD, Whitfield CH, Perry $\mathrm{BD}$ et all. The enduring effects of abuse and related adverse experiences in childhood. Eur Arch Psychiatry Clin Neurosci. 2006; 256(3):174-86.

7. Dube SR., Anda R.F., Felitti V.J., Edwards V.J., Croft J.B. Adverse childhood experiences and personal alcohol abuse as an adult. Addict Behav.2002; 27 (5):713-25.

8. Fenton MC, Geier T, Keyes K, Skodol AE, Grant BF, Hasin DS. Combined role of childhood maltreatment, family history, and gender in the risk for alcohol dependence. Psychol Med. 2013;43(05):1045-57.

9. Cibor R. Struktura "Ja” a motywy podejmowania leczenia odwykowego. Katowice; Wydawnictwo Uniwersytetu Śląskiego:1994.

10. Gross WF, Alder LO. Aspects of alcoholic's self-concepts as measured by the Tennessee Self-Concept Scale. Psychological Reports. 1970;27(2):431-4.

11. Kulpa A. Obraz samego siebie u osób z zespołem zależności alkoholowej. Problemy Alkoholizmu 1982;6 :9-10.

12. Brosowska W. Samoocena a przystosowanie społeczne u nałogowych alkoholików. Problemy Alkoholizmu. 1984;7-8:3233

13. Nikodemska S. Struktura ja, obraz siebie i radzenie sobie w sytuacji trudnej u pacjentów lecznictwa odwykowego. Świat Problemów. 2003;10: 4-7

14. Szczukiewicz P. Osobowość nałogowa .Świat Problemów. 2004;3:14-17

15. Aubry C, Gay MC, Romo L, Joffre S. L'image de soi de l'alcoolodépendant à travers l'échelle Tennessee du concept de soi. Encephale.2004; 30(1):24-31.

16. Lopez MA, Heffer RW. Self-concept and social competence of university student victims of childhood physical abuse. Child Abuse Negl.1998;22(3):183-95.

17. Giant CL,Vartanian LR. Experiences with parental aggression during childhood and self-concept in adulthood: The importance of subjective perceptions.J Fam Violence. 2003;18(6):361-7.

18. Turner HA, Butler MJ. Direct and indirect effects of childhood adversity on depressive symptoms in young adults. J Youth Adolesc.2003;32(2):89-103.

19. Cavaiola AA, Schiff M. Self-esteem in abused chemically dependent adolescents. Child Abuse Negl. 1989;13(3):327-34.

20. Moran PB, Eckenrode J. Protective personality characteristics among adolescent victims of maltreatment. Child Abuse Negl. 1992;16(5):743-54.

21. Śpila B, Makara M, Chuchra M., Grzywa A. Polska adaptacja Inwentarza Wczesnej Traumy (ETI).Wiadomości Psychiatryczne. 2005;8(1):20-4.

22. Gerhant A, Olajossy M. Personality traits in alcohol-dependent individuals in the context of childhood abuse. Psychiatr Pol. 2016;50(5):973-987.

23. Matkowski M. Test Przymiotnikowy jako narzędzie do badania struktury potrzeb jednostki. Przegląd Psychologiczny.1984;17(2):519-36.

24. Selzer ML.The Michigan Alcoholism Screening Test (MAST): The quest for a new diagnostic instrument. Am J
Psychiatry.1971;127:1653-58.

25. Falicki Z, Karczewski J, Wandzel L, Chrzanowski W. Usefulness of the Michigan Alcoholism Screening Test (MAST) in Poland. Psychiatr Pol. 1989; 20:38-42.

26. Raistrick D, Dunbar G, Davidson R. Development of a questionnaire to measure alcohol dependence. Br J Addict. 1983;78(1):89-95.

27. Ziółkowski M. Ocena skuteczności farmakoterapii w zapobieganiu nawrotowi picia u mężczyzn uzależnionych od alkoholu: praca habilitacyjna. Bydgoszcz; Wydawnictwo Uczelniane AM :1999.

28. Beck AT, Wright FD, Newman CF, Liese BS. Cognitive Therapy of Substance Abuse.New York; The Guilford Press :1998.

29. Finkelhor D, Browne A. The traumatic impact of child sexual abuse: A conceptualization. A J Orthopsychiatry.1985;55(4):530-41

30. Booth BM, Russell DW, Soucek S, Laughlin PR. Social support and outcome of alcoholism treatment: An exploratory analysis. Am J Drug Alcohol Abuse. 1992;18(1):87-101.

31. Groh DR, Jason LA, Keys CB. Social network variables in alcoholics anonymous: A literature review. Clin Psychol Rev. 2008;28(3):430-50.

32. Rosen CS, Ouimette PC, Sheikh JI, Gregg JA, Moos RH. Physical and sexual abuse history and addiction treatment outcomes. J Stud Alcohol. 2002;63(6):683-7.

33. Bętkowska-Korpała B. Osobowość w Modelu Wielkiej Piątki a utrzymywanie abstynencji od alkoholu przez rok od rozpoczęcia leczenia. Psychiatr Pol.2012; 46(3):397-9.

34. Chung T, Langenbucher J, Labouvie E, Pandina RJ, Moos RH. Changes in alcoholic patients' coping responses predict 12-month treatment outcomes. J Consult Clin Psychol .2001:69(1):92-100.

35. Brems C, Namyniuk L. The relationship of childhood abuse history and substance use in an Alaska sample. Subst Use Misuse.2002;37(4):473-94.

36. Dube SR, Miller JW, Brown DW, Giles WH, Felitti VJ, Dong M, Anda RF.Adverse childhood experiences and the association with ever using alcohol and initiating alcohol use during adolescence. J Adolesc Health. 2006;38(4):444.e1-10.

37. Zlotnick C, Johnson DM, Stout RL, Zywiak WH, Johnson JE, Schneider RJ. Childhood abuse and intake severity in alcohol disorder patients. J Trauma Stress. 2006;19(6):949-59.

38. Waldrop AE, Santa Ana EJ, Saladin ME, McRae AL, Brady KT. Differences in early onset alcohol use and heavy drinking among persons with childhood and adulthood trauma. Am J Addict. 2007;16(6):439-44.

39. Rothman EF, Edwards EM, Heeren T, Hingson RW.Adverse childhood experiences predict earlier age of drinking onset: results from a representative US sample of current or former drinkers. Pediatrics. 2008;22(2):298-304.

40. Miller BA, Mancuso RF. Connecting childhood victimization to later alcohol/drug problems: Implications for prevention. J Prim Prev.2004;25(2):149-69.

41. Aranowska E, Chachaj L, Morawski J. Three versions of alcoholism: MAST, SADD, RDC. W: Piotrowski A, Leder S, Gawrońska B.red. Alcoholism and other Dependencies. Warszawa; Polish Psychiatric Association:1989:195-203.

42. Westermeyer J, Wahmanholm K, Thuras P. Effects of childhood physical abuse on course and severity of substance abuse. Am J Addict. 2001;10(2):101-10.

43. Liebschutz J, Savetsky JB, Saitz R, Horton NJ, Lloyd-Travaglini C, Samet JH. The relationship between sexual and physical abuse and substance abuse consequences. J Subst Abuse Treat. 2002;22(3):121-8. 
44. Anda RF, Whitfield CL, Felitti VJ, Chapman D, Edwards VJ, Dube SR, Williamson DF. Adverse childhood experiences, alcoholic parents, and later risk of alcoholism and depression. Psychiatr Serv. 2002;53(8):1001-9.

45. Fenton MC, Geier T, Keyes K, Skodol AE, Grant BF, Hasin DS. Combined role of childhood maltreatment, family history, and gender in the risk for alcohol dependence. Psychol Med. 2013;43(05):1045-57.

46. Kessler RC, Borges G, Walters EE. Prevalence of and risk factors for lifetime suicide attempts in the National Comorbidity Survey. Arch Gen Psychiatry.1999;56(7):617-26.

47. Wilcox HC, Conner KR, Caine ED. Association of alcohol and drug use disorders and completed suicide: an empirical review of cohort studies. Drug Alcohol Depend. 2004;76, Suppl:11-19.

48. Bácskai E, Czobor P, Gerevich J. Suicidality and trait aggression related to childhood victimization in patients with alcoholism. Psychiatry Res.2009;165(1):103-10

49. Roy A, Jana N. Risk factors for suicide attempts among alcohol dependent patients. Arch Suicide Res. 2007;11(2):211-17.

50. Chodak M, Barwiński Ł. Autoagresja jako forma radzenia sobie ze stresem- przegląd zagadnień. Self-aggression as a form of coping with stress-a reviewof issues. Psychiatria i Psychoterapia 2010;6(1):19-30.

51. Briere J, Gil E. Self-mutilation in clinical and general population samples: prevalence, correlates, and functions. Am J Orthopsychiatry. 1998;68 (4):609-20.

52. Evren C, Sar V, Evren B, Dalbudak E. Self-mutilation among male patients with alcohol dependency: the role of dissociation. Compr. Psychiatry 2008; 9(5): 489-495.

53. Evren C, Evren B. Self-mutilation in substance-dependent patients and relationship with childhood abuse and neglect, alexithymia and temperament and character dimensions of personality. Drug Alcohol Depend. 2005:80(1):15-22.

54. Evren C, Cinar O, Evren B, Celik S. Self-mutilative behaviors in male substance-dependent inpatients and relationship with anger and aggression: mediator effect of childhood trauma. Compr Psychiatry.2012;53(3):252-258.

\section{Corresponding author}

Aneta Gerhant

II Department of Psychiatry and

Psychiatric Rehabilitation

Medical University of Lublin

Głuska 2 Street,

20-439 Lublin, Poland

+48817440967

aneta.gerhant@op.pl

Otrzymano:28.10.2019

Zrecenzowano:23.11.2019

Przyjęto do druku: 03.12.2019 